\title{
Costs Associated With Propane Vehicle Fueling Infrastructure
}

Factors to consider in the implementation of fueling stations and equipment

Margaret Smith, New West Technologies (DOE HQ Technical Support) John Gonzales, National Renewable Energy Laboratory

This document has been peer reviewed by the propane industry.

August 2014
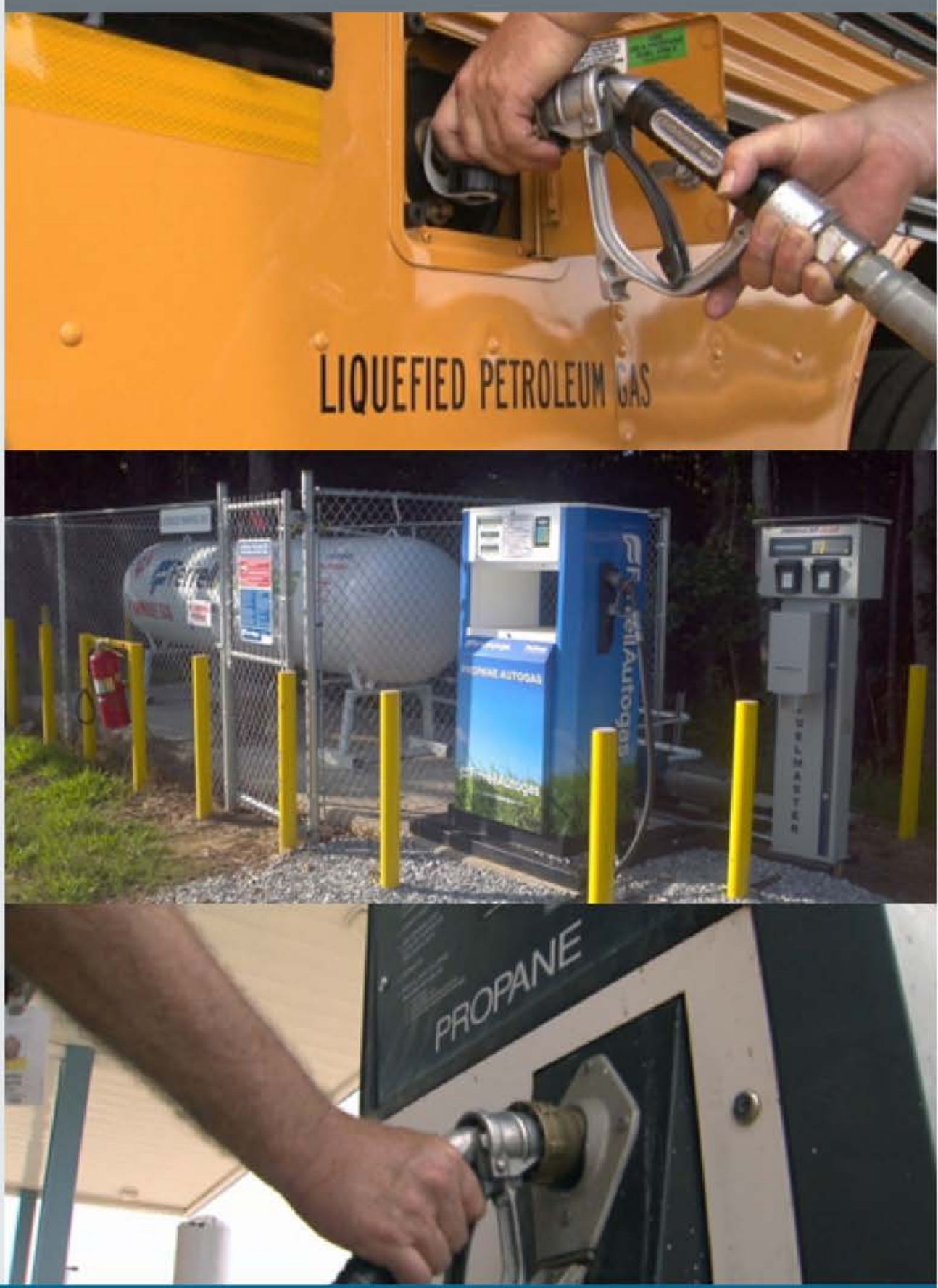

\section{U.S. Department of Energy}




\section{Introduction}

This document is designed to help fleets understand the cost factors associated with propane vehicle fueling infrastructure. It provides an overview of the equipment and processes necessary to develop a propane fueling station and offers estimated cost ranges. The information presented is based on input from propane industry professionals who design, sell equipment for, or own propane stations.

The costs associated with developing and operating a propane fueling station vary substantially according to the fuel storage capacity, the size of the fleet, and the market it serves (retail station setups have substantially greater capacities than basic fleet setups). We provide cost approximations across a range of storage capacity and fuel use scenarios. The total cost of developing a propane station depends on a number of factors, and costs can vary widely from one project to another, based on the specific needs of the fleet and other users, the complexity of equipment installation, and the permitting processes. This document outlines such factors for fleets' consideration but is not intended to be a tool for estimating the cost of an individual project. To obtain an estimate for a specific project, contact a propane provider or a registered professional engineer affiliated with the National Propane Gas Association or one of its state propane gas association partners.

\section{Propane Station Overview}

Across the United States, more than 2,000 public and private fueling stations offer propane (also known as liquefied petroleum gas or autogas). Propane is delivered to a station by a transport truck and stored in tanks, typically located above ground. Propane fueling dispensers are similar to gasoline dispensers, and they can be located near each other at fueling stations.

Skid-mounted propane stations, which are at the lower end of the cost range, are compact.

Installations require little labor or construction. Typical skidmounted units have a 1,000 - or 2,000-gallon storage tank. Sometimes two 1,000-gallon tanks are more cost effective than a 2,000-gallon tank. These tanks are commonly filled one to five

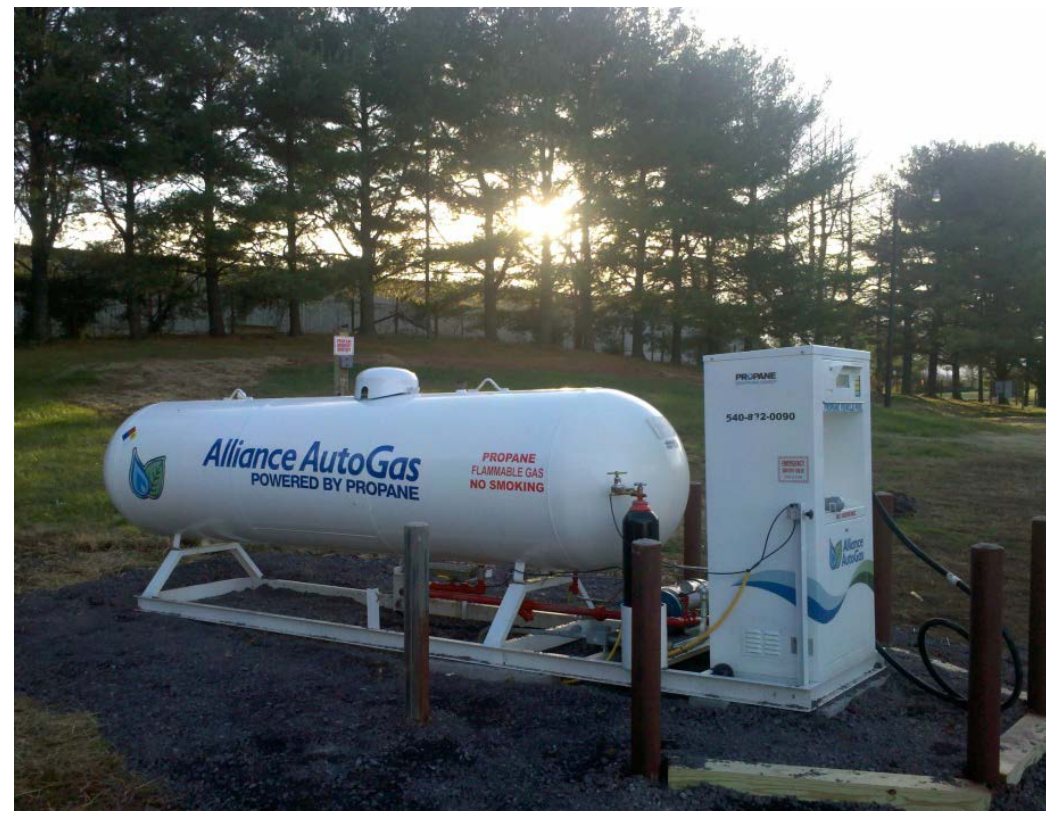

Skid-mounted 1,000-gallon propane storage tank and dispenser. Photo from Blossman Gas, Inc., NREL 30340 times per week, depending on the fleet's needs. 
Owners of larger stations often choose storage tanks with sufficient capacity to accept a full transport load (a full truck from the supplier) in order to receive fuel pricing benefits. The transport load size is typically 9,000 to 12,000 gallons. These storage tanks are filled as needed, depending on the tank size and the fleet's or customers' needs.

Many propane suppliers offer a cost-effective lease of the tank, pump, and dispensing equipment in return for a fuel supply contract. In these cases, the station owner is responsible for the costs of infrastructure (such

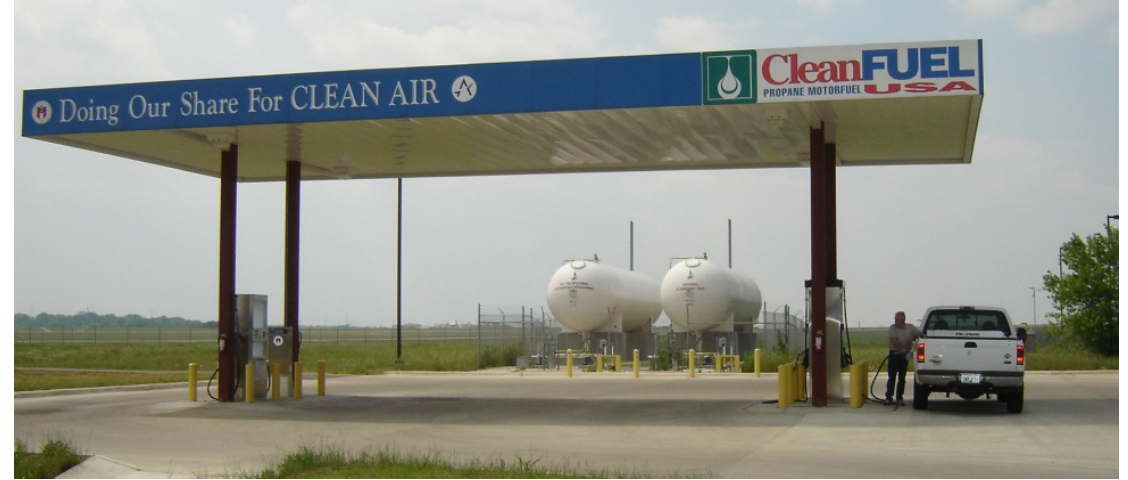

Austin-Bergstrom International Airport self-service propane station with twin 18,000-gallon tanks. Photo from CleanFUEL USA, NREL 28220 as the concrete pad, vehicle crash protection, electricity line, and connection to the fuel management system) that cannot be removed from the site when the fuel contract has expired. Equipment and installation costs are amortized in the fuel supply contract.

\section{Factors Impacting Propane Station Costs}

The most significant costs associated with developing a station are those related to equipment, station design, and installation. Approximated cost ranges are provided below, but actual costs of a given project will vary according to the specific needs and constraints of the station and its users.

\section{Propane Station Equipment}

Station equipment costs will vary based on equipment size, specifications, and manufacturer.

Storage Tank and Filling ( $\$ 5,000$ to $\$ 100,000)$

- Propane is delivered to the site by a bulk truck and stored in an onsite tank. A fleet should select a storage tank size based on the fleet's fuel use and the frequency of fills.

- Used propane tanks may be available for purchase and could cost less than new tanks.

- The fleet manager and the fuel supplier work together to determine the communication procedure for filling a propane storage tank. Options include:

○ A fleet manager has the tank filled at a specified frequency, such as once per week.

○ The tank is monitored with a sensor that notifies the supplier when filling is necessary.

- A fleet manager tracks the fuel use and submits tank fill requests based on fleet needs and fuel pricing. In this case, the fleet manager should ensure the tank does not completely empty between fills, as this may damage equipment and prevent the tank from being able to fuel vehicles. 
Dispenser $(\$ 5,000$ to $\$ 35,000)$

- The dispenser manages the propane that is delivered into the vehicle. It can vary in complexity and cost depending on the enclosure material, fueling flow rate, number of hoses, electrical system, size of pump motor, and fuel management system.

- Additional dispenser hoses reduce wait times by allowing more vehicles to fuel simultaneously. Depending on the station design and the dispensing rate, adding more dispensers may require purchasing a larger pump and motor.

Pump and Motor $(\$ 4,000$ to $\$ 15,000$ )

- The motor is connected to the electrical setup and powers the pump. The pump pushes propane from the storage tank and to the dispenser, which delivers it to the vehicle via the hose.

- Propane generators can be used to run the motor during a power outage and are assets in an emergency preparedness plan. Propane generator costs can range from $\$ 3,000$ to

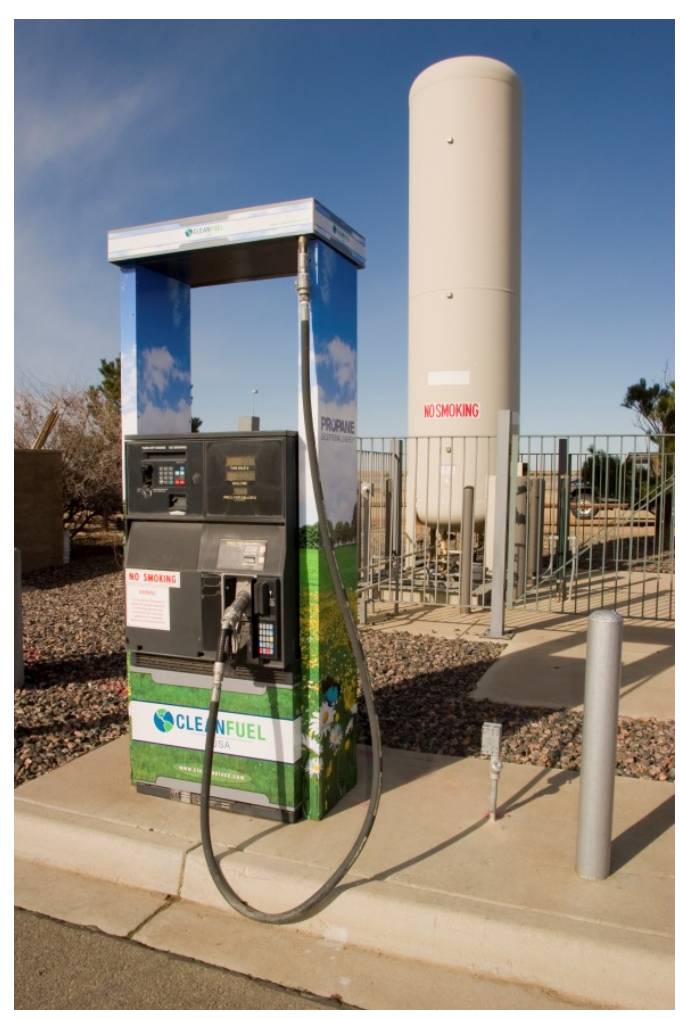

Propane dispenser and 2,000-gallon tank. Photo from CleanFUEL USA, NREL 28219 $\$ 10,000$, depending on the pump and motor size.

Fuel Management System $(\$ 5,000$ to $\$ 30,000)$

- The fuel management system monitors and tracks the flow of fuel delivered to the vehicle. It can vary in complexity from a simple card reader to a full-service tracking system of driver and vehicle fueling history.

\section{Design and Installation}

\section{Installation and Site Preparation}

Propane station development typically involves installation costs, such as those associated with crash protection, plumbing, electrical connection, concrete foundation, and material shipping. Many factors affect site preparation costs, including:

- Site layout, such as distance to buildings, property lines, and sources of ignition

- Distance from propane tank to dispenser

- Availability of electrical power

- Running a water line for a sprinkler or water monitor deluge system 
- Signage, lighting, and security fencing, as needed

- Availability of other types of fuels to be dispensed at the same location

- Site preparation, as necessary

- Physical dimensions of the vehicles the station will serve.

\section{Regulatory and Permitting Issues}

Regulatory and permitting issues can contribute to the cost of the station or even make the station cost prohibitive. Engaging the authority having jurisdiction (typically a fire marshal) at the project outset will simplify the permitting process. It will also ensure compliance with relevant National Fire Protection Association codes. Permitting may be easier for smaller, skid-mounted systems. Americans with Disabilities Act compliance may also affect the cost of the station or other facility design parameters.

\section{Planning for Growth}

Some fleet managers initially lease a smaller tank when transitioning to propane. As propane use increases, they may lease or purchase equipment for larger station throughput. Skid-mounted systems are convenient for growing fleets because they can be easily replaced with larger systems.

\section{Propane Lawn Equipment}

Many landscape companies, parks, and other organizations with turf management operations are powering their mowing equipment with propane. Typically, empty propane cylinders are removed from the lawn equipment and stored in a cage onsite. A propane provider fills the cylinders in the cage or replaces empty cylinders with full ones each week. Less commonly, the fleet installs a small propane station with a 500-gallon tank to fill cylinders.

\section{Mobile Onsite Fueling}

Mobile onsite fueling, also known as wet hosing, is an option for propane fueling. Vehicles return to the

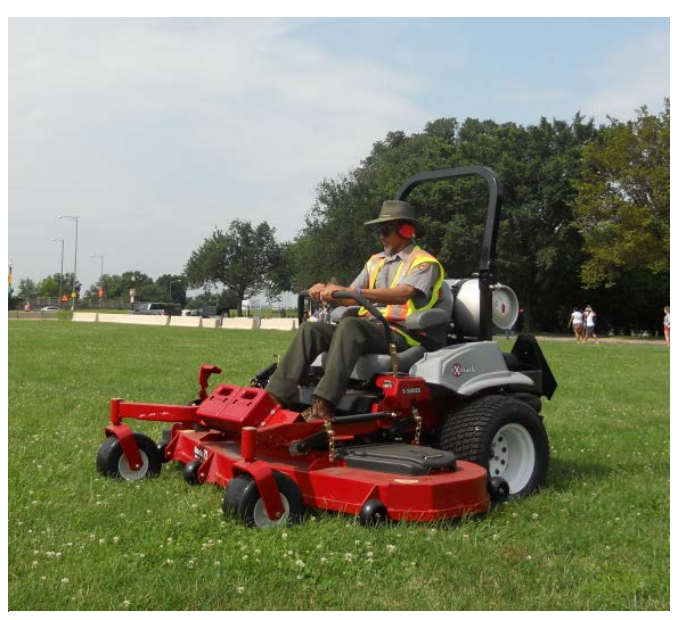

A National Park Service employee operates a propane-powered mower at the National Mall in Washington, D.C. Photo from Julie Sutor, NREL 26748. fleet facility in the evening, and a propane supplier fuels the vehicles while they are not on duty. A fleet may choose this option instead of building onsite infrastructure for cost or convenience benefits. Fleets also use it as a temporary fueling arrangement if propane vehicles arrive before infrastructure is operational or if infrastructure is out of service. Some propane suppliers prefer to use wet hosing under emergency circumstances only. A fleet should consult local code authorities to identify any restrictions to mobile fueling.

\section{Pump Redundancy}

Incorporating pump redundancy (a backup system) in the station design will allow the station to continue operating if a pump stops functioning. The additional equipment will increase station cost but improve reliability. 


\section{Geographic Location and Weather}

Geographic location and weather impact the costs of equipment, installation, and permitting. In extreme cold climates, more elaborate equipment may be needed, including additional heaters. Regions prone to earthquakes may have seismic design requirements. Inclement weather during construction can add to installation costs. For example, a project may incur expenses related to keeping water out of trenches. Equipment and construction costs vary from one region to the next.

\section{Offsite Fueling Network}

In some areas of the country, a network of offsite fueling facilities may be available to serve a fleet's needs. These facilities are accessed by members of a private network through a certification card and may not have fueling attendants present. This system allows multiple propane vehicle fleets in a particular geographic area to use the same infrastructure.

\section{Cost Estimates}

The tables below provide cost estimates for propane fueling stations of various sizes. In the "Cost Range" column, two estimates are included for each scenario: the first includes the costs of purchasing new equipment and installation at a typical site; the second includes the initial costs a fleet manager will incur if he or she enters into a leasing agreement with a fuel provider. Notably, the scenarios below may differ significantly from the actual operations of a particular fleet. This is important, given that the frequency with which a station's storage tank is filled depends on the tank's capacity and the specific fueling demand of the fleet in question. As mentioned, the costs of a given project will vary according to the specific needs and constraints of the station and its users.

Small Stations (Skid-Mounted)

\begin{tabular}{|c|c|c|c|c|}
\hline Station Design & $\begin{array}{l}\text { Approx. Daily } \\
\text { Fuel Use* }\end{array}$ & Cost Range & Example Applications* & \\
\hline $\begin{array}{l}\text { 1,000-gal } \\
\text { storage tank } \\
1 \text { single-hose } \\
\text { dispenser }\end{array}$ & $\begin{array}{l}100-400 \text { gal } \\
\text { (If tank is filled } \\
\text { every } 2 \text { weeks to } \\
2 \text { times/wk) }\end{array}$ & $\begin{array}{c}\text { Purchasing New } \\
\text { Equipment: } \\
\$ 45,000-\$ 60,000 \\
\text { Initial Cost for Leasing: } \\
\$ 3,000-\$ 10,000\end{array}$ & $\begin{array}{l}3 \text { school buses } \times 16 \text { gal } / \text { day, } \\
10 \text { shuttle vans } \times 20 \text { gal } / \text { day, or } \\
30 \text { taxis } \times 7 \text { gal } / \text { day }\end{array}$ & 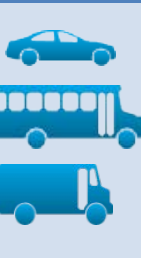 \\
\hline $\begin{array}{c}2,000 \text { gal } \\
\text { storage with } \\
\text { twin } 1,000 \text {-gal } \\
\text { tanks } \\
1 \text { dual-hose } \\
\text { dispenser }\end{array}$ & $\begin{array}{l}200-800 \text { gal } \\
\text { (If tank is filled } \\
\text { every } 2 \text { weeks to } \\
2 \text { times/wk) }\end{array}$ & $\begin{array}{c}\text { Purchasing New } \\
\text { Equipment: } \\
\$ 60,000-\$ 70,000 \\
\text { Initial Cost for Leasing: } \\
\$ 5,000-\$ 12,000\end{array}$ & $\begin{array}{l}20 \text { school buses } \times 15 \text { gal } / \text { day } \\
30 \text { shuttle vans } \times 18 \text { gal/day } \\
60 \text { taxis } \times 7 \text { gal } / \text { day, } \\
65 \text { delivery vans } \times 6 \text { gal } / \text { day, or }\end{array}$ & 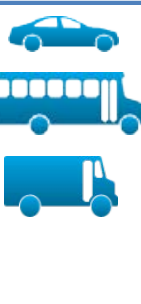 \\
\hline
\end{tabular}




\section{Medium Stations}

\begin{tabular}{|c|c|c|c|}
\hline Station Design & $\begin{array}{c}\text { Approx. Daily Fuel } \\
\text { Use* }\end{array}$ & Cost Range & Example Applications* \\
\hline $\begin{array}{l}\text { 12,000-gal } \\
\text { storage tank } \\
2 \text { dual-hose } \\
\text { dispensers }\end{array}$ & $\begin{array}{c}450-1,800 \text { gal } \\
\text { (If tank is filled } \\
\text { with } 1-3 \text { transport } \\
\text { loads/mo) }\end{array}$ & $\begin{array}{c}\text { Purchasing New } \\
\text { Equipment: } \\
\$ 120,000-\$ 145,000 \\
\text { Initial Cost for } \\
\text { Leasing: } \\
\$ 15,000-\$ 50,000\end{array}$ & $\begin{array}{l}35 \text { school buses } \times 14 \mathrm{gal} / \mathrm{day} \text {, } \\
65 \text { police cruisers } \times 7 \mathrm{gal} / \mathrm{day} \text {, or } \\
100 \text { shuttle vans } \times 20 \mathrm{gal} / \mathrm{day}\end{array}$ \\
\hline $\begin{array}{l}\text { 18,000-gal } \\
\text { storage tank } \\
3 \text { dual-hose } \\
\text { dispensers }\end{array}$ & $\begin{array}{c}\text { 900-2,400 gal } \\
\text { (If tank is filled } \\
\text { with } 2-4 \text { transport } \\
\text { loads/mo) }\end{array}$ & $\begin{array}{c}\text { Purchasing New } \\
\text { Equipment: } \\
\$ 150,000-\$ 220,000 \\
\text { Initial Cost for } \\
\text { Leasing: } \\
\$ 15,000-\$ 50,000\end{array}$ & $\begin{array}{l}60 \text { school buses } \times 16 \text { gal } / \text { day, } \\
70 \text { shuttle vans } \times 20 \text { gal/day, } \\
100 \text { school buses } \times 10 \text { gal/day, or } \\
150 \text { taxis } \times 10 \text { gal } / \text { day }\end{array}$ \\
\hline
\end{tabular}

\section{Large Stations}

\begin{tabular}{|c|c|c|c|}
\hline $\begin{array}{l}\text { Station } \\
\text { Design }\end{array}$ & $\begin{array}{l}\text { Approx. Daily } \\
\text { Fuel Use* }\end{array}$ & Cost Range & Example Applications* \\
\hline $\begin{array}{l}\text { 30,000-gal } \\
\text { storage tank } \\
4 \text { dual-hose } \\
\text { dispensers }\end{array}$ & $\begin{array}{c}900-3,000 \text { gal } \\
\text { (If tank is filled } \\
\text { with } 2-5 \\
\text { transport } \\
\text { loads/mo) }\end{array}$ & $\begin{array}{c}\text { Purchasing New } \\
\text { Equipment: } \\
\$ 225,000-\$ 300,000 \\
\text { Initial Cost for Leasing: } \\
\$ 15,000-\$ 50,000\end{array}$ & $\begin{array}{l}70 \text { shuttle vans } \times 20 \text { gal } / \text { day, } \\
100 \text { delivery vans } \times 9 \text { gal/day, or } \\
250 \text { school buses } \times 10 \text { gal/day }\end{array}$ \\
\hline
\end{tabular}

*Daily fuel use and fleet sizes for each tank size can vary substantially.

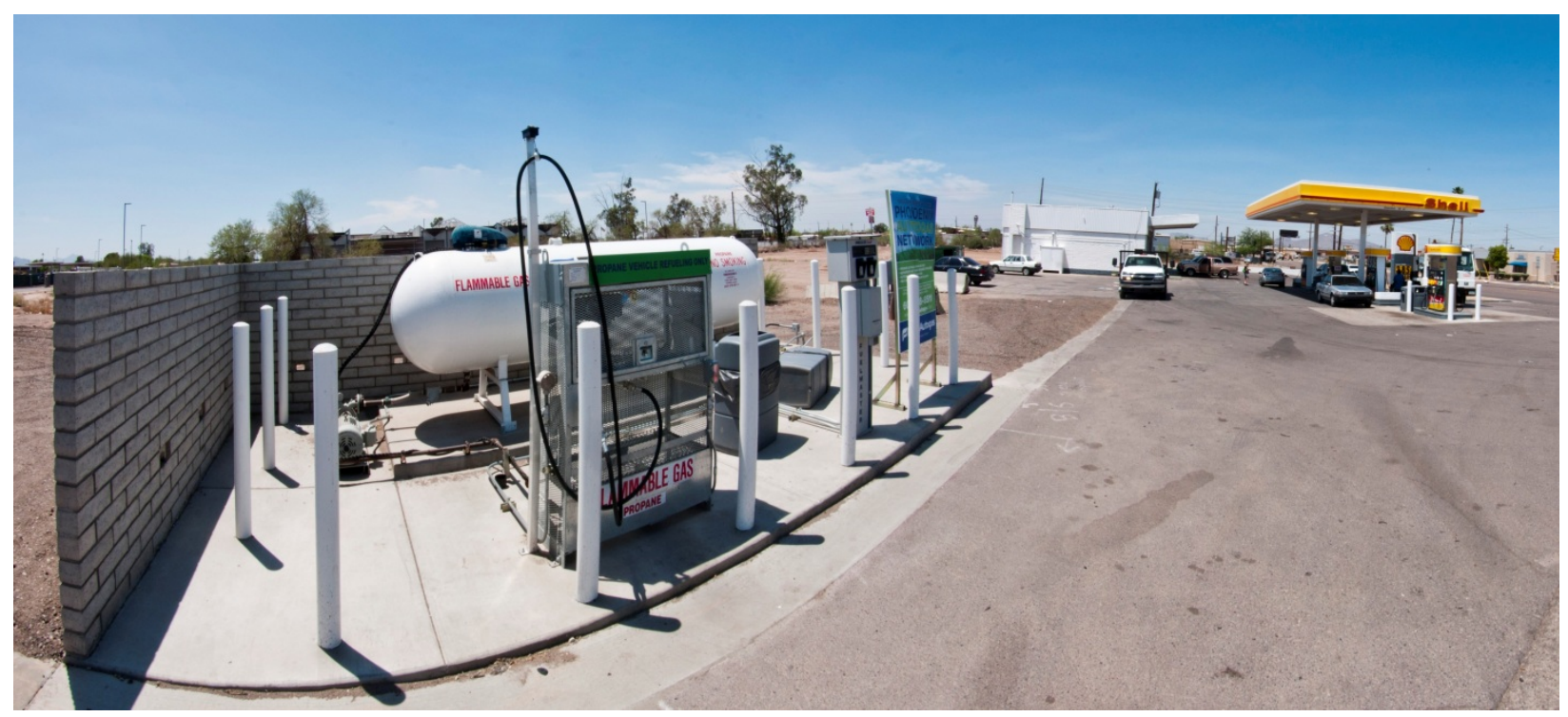

Propane station adjacent to a gasoline station in Phoenix, Arizona. Photo by Gabe R. DeWitt, NREL 30248 


\section{Additional Resources}

For more information about propane stations, visit the Alternative Fuel Data Center at afdc.energy.gov/fuels/propane infrastructure.html. To learn more about the topics introduced in this document, connect with your local Clean Cities coalition. Coalition contact information can be found at afdc.energy.gov/cleancities/coalitions/coalition_contacts.php.

Questions or comments about the information in this document can be sent to cleancities@,nrel.gov.

Front Cover Pictures Credits:

MotorWeek/Maryland Public TV, NREL 17166

Gabe R. DeWitt, NREL 30341

MotorWeek/Maryland Public TV, NREL 17176 
